\section{Pacific Northwest}

National Laboratory

Operated by Battelle for the

U.S. Department of Energy

\title{
Industrial Site Characterization: Federal Sector
}

K. McMordie-Stoughton

T. Koehler

March 2002

Prepared for the

U.S. Department of Energy

Office of Energy Efficiency and Renewable Energy

Federal Energy Management Program

under Contract DE-AC06-76RL01830 


\title{
Industrial Site Characterization: Federal Sector
}

\author{
K. McMordie-Stoughton \\ T. M. Koehler
}

March 2002

Prepared for

the U.S. Department of Energy

Office of Energy Efficiency and Renewable Energy

Federal Energy Management Program

under Contract DE-AC06-76RL01830

Pacific Northwest National Laboratory

Richland, Washington 99352 


\section{PREFACE}

The mission of the U.S. Department of Energy's Federal Energy Management Program (FEMP) is to reduce the cost of Government by advancing energy efficiency, water conservation, and the use of solar and other renewable technologies. This is accomplished by creating partnerships, leveraging resources, transferring technology, and providing training and technical guidance and assistance to agencies. Each of these activities is directly related to achieving the requirements set forth in the Energy Policy Act of 1992 and the goals that have been established in Executive Order 13123 (June 1999), as well as supporting activities that promote sound management of Federal financial and personnel resources. The Pacific Northwest National Laboratory (PNNL) supports the FEMP mission in all activity areas.

Section 203 of Executive Order 13123 requires all Federal agencies to reduce energy consumption. While there is an exemption for Federal laboratories and research and development facilities, industrial facilities do not fall under this program. The goal of this task was to identify and characterize key industrial Federal sites to assist in establishment of a support program for energy reduction in Federal industrial facilities. This document identifies key industrial sites in both the Defense Department and civilian agencies that could be prime candidates for energy-efficiency improvements. For these targeted agencies, location, gross square footage, and site energy consumption, cost and general industrial process information is provided (if available).

This work was conducted as part of the FEMP Industrial Program, which is directed by Alison Thomas. Her support and assistance are greatly appreciated. 


\section{SUMMARY}

Pacific Northwest National Laboratory (PNNL) was funded by FEMP in FY01 to identify the key industrial sites in the Federal sector that are good candidates for energy-efficiency projects. PNNL researched a variety of data sources and documents to 1) understand how the Federal government classifies industrial facilities; 2) screen Federal agencies to identify the key agencies that have industrial activities; and 3) locate the large, energy intensive Federal industrial complexes and the energy intensive processes that are used. Through this research, the dominant agencies that have large energy intensive industrial processes have been identified to be:

- Department of Defense (DOD)

- Department of Energy (DOE)

- National Aeronautics and Space Administration (NASA).

\section{DEPARTMENT OF DEFENSE}

Within the Department of Defense, the Army has the majority of the industrial facilities. The key type of Army industrial facilities are arsenals, ammunition plants, and depots, where weapons are produced and vehicles and equipment is repaired and serviced. The key Army sites identified in this report are listed below:

- Rock Island Arsenal

- Pine Bluff Arsenal

- Watervliet Arsenal

- Picatinny Arsenal

- Corpus Christi Depot

- Tobyhanna Depot

- Letterkenny Depot

- Red River Depot

- Anniston Depot

- Hawthorne Depot

- Scranton Ammunitions Plant

- Radford Ammunitions Plant

- Lake City Ammunitions Plant

- Holston Ammunitions Plant

- Milan Ammunitions Plant

- McAllester Ammunitions Plant.

The primary Air Force industrial facilities are located at the Air Force Logistics Centers. These Air Force Bases have the main responsibility for the maintenance and repair of Air Force equipment, aircraft, and vehicles. The key industrial Air Force sites are listed below:

- Tinker Air Force Base

- Warner Robins Air Force Base 
- Hill Air Force Base

The Navy's primary industrial complexes are at Naval Ship Yards, where all Navy ships and related equipment are repaired, overhauled, and maintained, which includes the mechanical, electrical, and structural overhaul. The sites identified are listed below:

- Long Beach Naval Ship Yard

- Portsmouth Naval Ship Yard

- Norfolk Naval Ship Yard

- Bremerton Naval Ship Yard.

\section{CIVILIAN AGENCIES}

Within the civilian agencies, the Department of Energy (DOE) has three key industrial facilities that are listed below:

- Kansas City Plant

- Sandia National Laboratory

- Petroleum and Oil Reserves.

National Aeronautics and Space Administration's industrial sites are facilities that produce and maintain equipment and parts for space craft:

- Michoud Assembly Facility

- NASA Industrial Plant

- Marshall Space Flight Center.

It is the intent of the authors that this information be utilized by FEMP to assist in targeting large Federal industrial sites for energy projects. The report details the location, energy use data including annual energy consumption and cost information, and key industrial processes to provide the type of information needed for characterizing and prioritizing sites for energy-efficiency projects. 


\section{ABBREVIATIONS}

\section{FEDERAL AGENCIES}

Department of Energy $\quad$ DOE

Department of Defense DOD

Department of Justice DOJ

Environmental Protection Agency EPA

Federal Energy Management Program $\quad$ FEMP

General Services Administration $\quad$ GSA

Health and Human Services $\quad$ HHS

National Aeronautics and Space Administration NASA

State Department $\quad$ State

Tennessee Valley Authority $\quad$ TVA

$\begin{array}{ll}\text { Treasury Department } & \text { TRSY }\end{array}$

U.S. Department of Agriculture USDA

\section{ENGINEERING UNITS}

Billions $\quad$ B

British thermal units $\quad$ Btu

Cubic-feet cu.ft.

Million $\quad M$

Square-foot $\quad$ sf

Thousands $\mathrm{K}$

Watt-Hour $\quad$ Wh

Year $\quad \mathrm{yr}$ 


\section{CONTENTS}

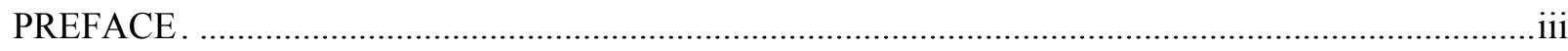

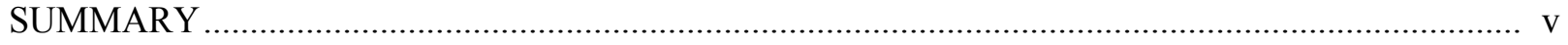

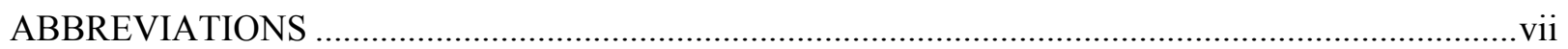

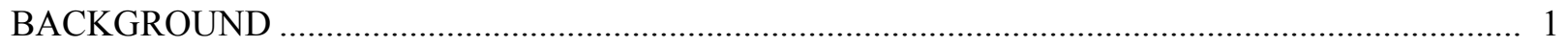

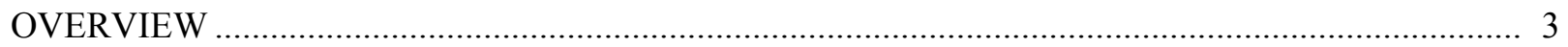

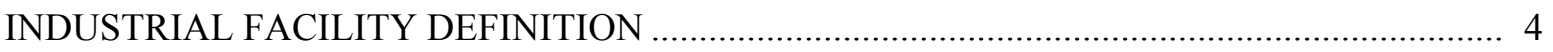

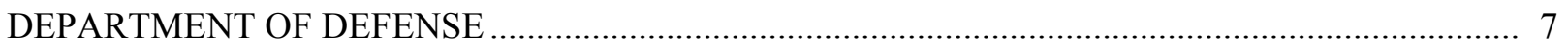

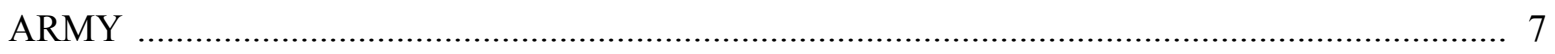

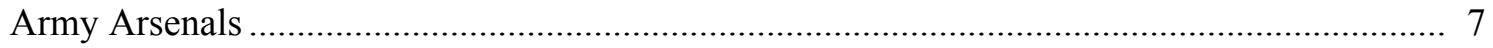

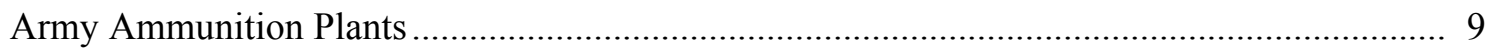

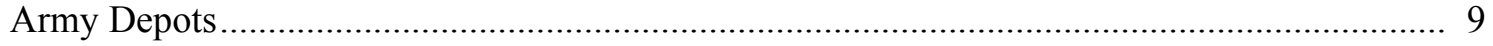

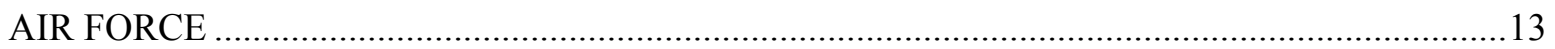

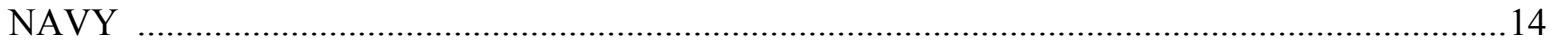

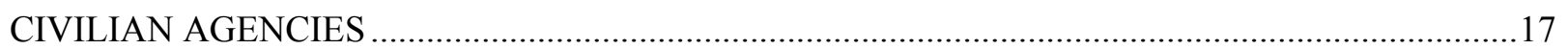

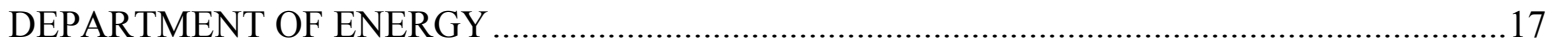

NATIONAL AERONAUTICS AND SPACE ADMINISTRATION..............................................19

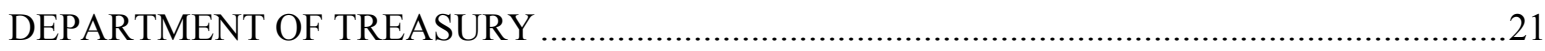

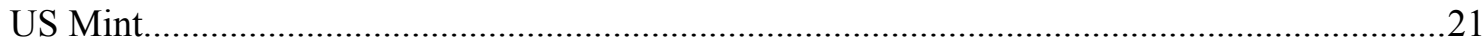

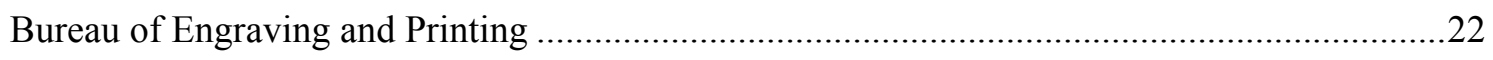

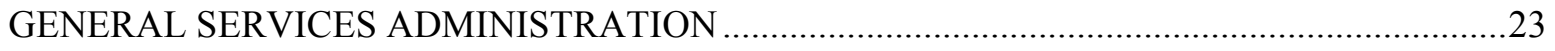

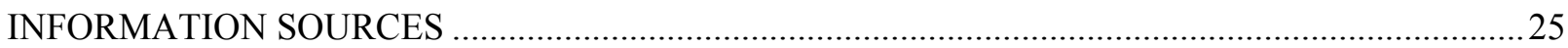




\section{FIGURES}

1 Federal Energy Intensive Operations Total Energy FY 2002 (BBtu) .......................................... 3

\section{TABLES}

1 Site Energy Consumption of Key Army Industrial Sites - FY 2000 REEP Installation Data ...........12

2 Site Energy Consumption of Key Air Force Industrial Sites - FY 1997 REEP Installation Data .....15

3 Site Energy Consumption of Key Naval Industrial Sites - FY 1998 Navy Data ............................15

4 Process Energy Consumption of Key DOE Industrial Sites - FY 1997_.......................................18

5 Energy-Intensive Facility Energy Consumption of Key NASA Industrial Sites - FY 2000 ...........20 


\section{BACKGROUND}

Section 203 of Executive Order 13123 (June 1999) requires all Federal agencies to reduce energy consumption per square foot, per unit of production, or per other unit as applicable in industrial and laboratory facilities by $20 \%$ by 2005 and $25 \%$ by 2010 relative to 1990 . Under the program titled Laboratories for the $21^{\text {st }}$ Century, Federal laboratories and research and development facilities receive support and guidance on energy reduction strategies. However, industrial facilities do not fall under this program. At the present time, there is no official program that assists Federal industrial facilities in energy reduction. Therefore, the aim of this task is to identify and characterize key industrial Federal sites as the first step toward establishing a support program for energy reduction for industrial facilities. To this aim, several questions need to be answered to assist in identification of ways to meet the goal for Federal industrial facilities and assist in developing the overall FEMP program direction.

1) What is the relative mix of industrial facilities compared to laboratory facilities in the Federal sector?

2) What and where are the key large industrial Federal sites?

3) For identified industrial facilities, what are the types of processes used to target efficiency improvements?

This document identifies key industrial sites in both the Defense Department and civilian agencies and the general types of processes that exist at the sites that could be prime candidates for energy efficiency improvements. It is the intention of the authors to provide information to help in the development of the overall FEMP effort related to industrial program activities. 


\section{OVERVIEW}

For FY 2000, Federal agencies reported annual energy use to FEMP in three categories:

\section{1) Standard Buildings and Facilities}

2) Energy Intensive Operations: industrial, laboratory, and other energy intensive facilities

3) Exempt Buildings: Buildings that were not occupied or were being either commissioned or decommissioned.

The definitions of these categories have changed from previous years. Previously, all buildings that were energy intensive were classified under the Exempt category and were excluded from all energy reduction goals because these types of facilities tended to be mission oriented and were more difficult to implement efficiency measures. However starting in FY 2000, facilities that were energy intensive were categorized into Energy Intensive Operations and were required to meet reduction goal of $20 \%$ by 2005 based on the baseline year of FY 1990.

The first step in characterizing large Federal industrial sites is to carefully identify which agencies report energy-intensive operations (EIOps), the associated energy use, and list indicators they used to identify specific sites or building types. Figure 1 below shows the agencies that reported EIOps for FY 2000 in billion British thermal units (BBtu).

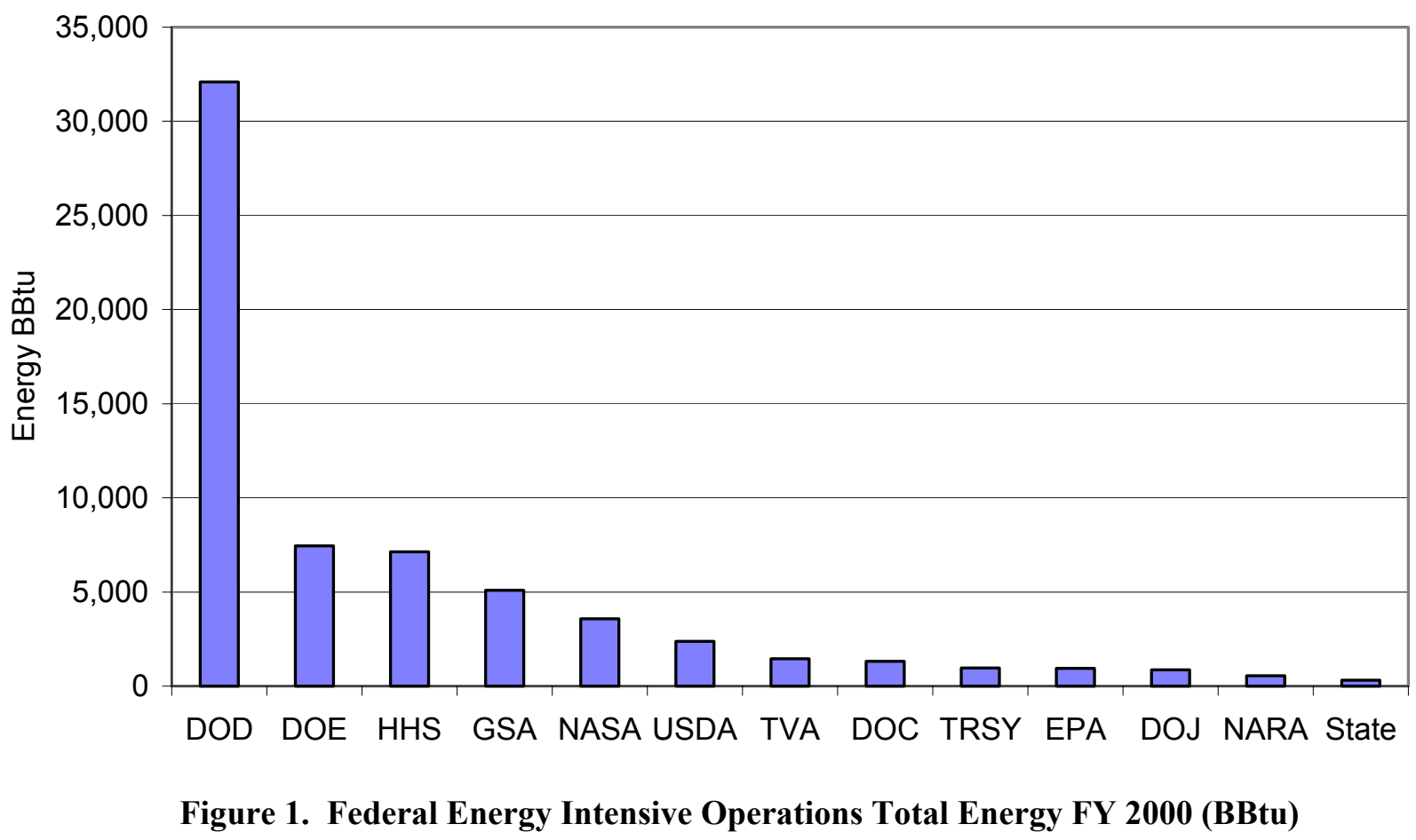


Once the agencies are identified, an important distinction to make among these agencies is the breakout of industrial facilities compared to research and development laboratories. Screening based on these two facility categories shows that DOD, DOE, and NASA dominate the industrial facility category. Also, the Department of Treasury (TRSY) has key industrial sites, and GSA has one large industrial steam plant. All of the other agencies with significant EIOps energy use (such as HHS and USDA) are predominantly laboratory and R\&D facilities. Agencies that are not listed in Figure 1 did not report EIOps for FY 2000.

For these targeted agencies, this document summarizes the following information for each selected facility:

- Location

- Gross square footage

- Site energy consumption and cost (if available)

- General industrial processes (if available)

Please note, if little or no information is listed on a particular site, this indicates that there was no website or contact available for the site at the time this report was prepared. If information is collected from those sites, this document may be updated and a revision issued.

\section{INDUSTRIAL FACILITY DEFINITION}

A key issue arose in developing this report - the question of what constitutes an industrial facility? It was discovered that agencies have slightly different definitions of industrial facilities (see GSA, DOE, and DOD's definitions below.) Therefore, instead of choosing one industrial definition, industrial facilities are identified by the mission of the facility. For example, many military shops use industrial processes such as heat-treating, welding, or paint stripping, but may not fall under the industrial category.

Therefore for the purposes of this report, an industrial facility is one that involves a process that manipulates or produces a product that is not directly associated with a research and development laboratory. In other words, if the facility is producing a product or overhauling/refurbishing components for the sole intent of utilizing the product for its inherent purpose, such as producing ammunition or repairing military aircraft for example, then the facility is considered industrial. For further information, the specific definitions of industrial facility for specific agencies are listed below.

\section{GSA's Definition of Industrial Facilities}

Buildings specifically designed and primarily used for production or manufacturing, such as the production or manufacturing of ammunition, aircraft, shops, vehicles, electronic equipment, chemicals, aluminum, and magnesium. 
DOE's (FEMP) Definition of "Industrial, Laboratory, Research, and Other Energy-Intensive Facilities" in EO 13123

Under the Order, industrial facilities should be classified as energy-intensive and be subject to the goals of Section 203. Section 706 defines "industrial facility" as "any fixed equipment, building, or complex for production, manufacturing, or other processes that uses large amounts of capital equipment in connection with, or as part of, any process or system, and within which the majority of energy use is not devoted to the heating, cooling, lighting, ventilation, or to service the water heating energy load requirements of the facility."

DOD's Definition of Industrial Process Energy, as defined in the report "Review of Department of Defense Industrial Processes and Process Energy" (Lin 1996)

"Industrial process energy is defined as the facility energy directly consumed in the manufacture, rehabilitation, or refurbishment, and the destruction of products such as tanks, aircraft, ships, ... and energy consumed in the movement of materials in automated warehouses. It excludes energy used for personal comfort, general administration, facility security, and housekeeping requirements."

Four main types of energy are discussed in the report:

1) Maintenance type processes

2) Explosive production

3) Metal processing

4) Loading, assembling, and packing. 


\section{DEPARTMENT OF DEFENSE}

The Department of Defense (DOD) is the largest industrial user in the Federal Government. DOD is involved in energy intensive industrial processes such as producing arsenals, ammunitions, and repairing and overhauling vehicles, ships, aircraft and other related equipment. At all major DOD industrial sites, the most common facilities that house industrial type processes are listed below:

- Heat treating shop

- Electroplating shop

- Motor rewind shop

- Painting and paint stripping shops

- Central compressed air system

- Central steam distribution.

These types of facilities usually use large motors, fans, and air compression units that will likely be key targets for energy-efficient improvements. Also, other retrofits including operations and maintenance $(\mathrm{O} \& \mathrm{M})$ measures (such as perform routine maintenance of steam lines and traps, insulate heated solutions, and automate processes with controls) are ideal energy reduction techniques that can reduce energy consumption.

The following sections list the largest industrial sites in the three major DOD services - Army, Air Force, and Navy. Information on location, energy use, site size, and typical processes are provided for each key site, as available.

\section{ARMY}

The primary industrial facilities in the Army are in the Army Material Command (AMC). The key industrial AMC facilities are arsenals, depots, and ammunition plants. These facilities are energy intensive and are most likely good targets for energy-efficiency projects.

\section{Army Arsenals}

The primary mission of arsenals is to produce weaponry for the Army. The four active arsenals are listed below, along with the arsenal's primary products and processes.

- Rock Island

- Pine Bluff

- Watervliet

- Picatinny

\section{Rock Island Arsenal}

Location: Rock Island, Illinois

Size: $6,521,000$ sq. $\mathrm{ft}$.

Website: http://www.ria.army.mil/ 
Rock Island Arsenal is the Army's leading facility for producing artillery/gun mounts and weapons integration. The arsenal has DOD's only metal manufacturing complex that can produce final products from the original raw material.

Products Manufactured:

- Artillery, gun mounts, recoil mechanisms, small arms, aircraft weapon sub-systems, weapons simulators, demolition of containers, and production of a host of spare and repair parts.

Processes used in Manufacturing:

- Forging, machining, finishing, foundry work, soft materials fabrication, tool, die and gauge manufacturing, spare and repair parts production, and prototype fabrication.

\section{Pine Bluff Arsenal}

Location: Pine Bluff, Arkansas

Size: 3,493,000 sq. ft.

Website: http://www.ria.army.mil/

Pine Bluff Arsenal produces conventional ammunition and products for chemical and biological protection, such as masks and clothing, including the testing and repair of these materials.

\section{Products Manufactured:}

- Conventional ammunition, chemical and biological protection.

Processes used in Manufacturing:

- Not known at this time.

\section{Watervliet Arsenal}

Location: Albany, New York

Size: 2,162,000 sq. ft.

Website: http://www.wva.army.mil/MFG1.HTM

Watervliet Arsenal is located in just north of Albany, New York and produces high-powered weaponry, primarily cannons.

Products Manufactured:

- Cannons, recoil rifles, mortars, and tank guns.

Processes used in Manufacturing:

- Machining, forging, casting, heat-treating, plating, surface coating, material fabrication.

\section{Picatinny Arsenal}

Location: Rockway, New Jersey

Size: $3,907,000$ sq. ft.

No other information was available. 


\section{Army Ammunition Plants}

Large industrial processes are housed at the Army's ammunition plants. Typically these plants produce explosives and propellants. The following list contains the key/active ammunition plants in the Army. No site-specific information was available on the sites' unique processes. However, the processes listed below would characteristically apply to ammunition plants:

- Heat treating

- Electroplating

- Motor rewind

- Painting and paint stripping

- Central compressed air system

- Central steam distribution.

\section{Scranton Ammunition Plant}

Location: Pennsylvania

Size: Not available at this time

\section{Radford Ammunition Plant}

Location: Radford, Virginia

Size: 4,369,000 sq. ft.

\section{Lake City Ammunition Plant}

Location: Kansas City, Missouri

Size: $3,165,000$ sq. ft.

\section{Holston Ammunition Plant}

Location: Kingsport, Tennessee

Size: $2,429,000$ sq. $\mathrm{ft}$.

\section{Milan Ammunition Plant}

Location: Milan, Tennessee

Size: 4,226,000 sq. ft.

McAllester Ammunition Plant

Location: McAllester, Oklahoma

Size: 9,805,000 sq. ft.

\section{Army Depots}

Army depots' main mission is to repair and service army equipment and vehicles. There are six active depots (listed below) with general information given on the services provided at each complex.

- Corpus Christi Depot

- Tobyhanna Depot

- Letterkenny Depot 
- Red River Depot

- Anniston Depot

- Hawthorne Depot

Corpus Christi Army Depot

Location: Corpus Christi, Texas

Size: $2,185,000$ sq. $\mathrm{ft}$

Website: http://www.ccad.army.mil/

Corpus Christi Depot is located in at the Naval Air Station in Corpus Christi, Texas. The depot's main mission is to repair, overhaul, and maintain a wide variety of helicopters and related engines and components

Services:

- Maintenance and repair of rotary wing DOD aircraft, aircraft crash analysis, and lubricating oil analysis.

\section{Tobyhanna Army Depot}

Location: Tobyhanna, Pennsylvania

Size: 4,512,000 sq. $\mathrm{ft}$

Website: http://www.tobyhanna.army.mil/

Located in Northeastern Pennsylvania, Tobyhanna Depot is a part of the Communications-Electronics Command with the primary assignment of repairing, overhauling and fabricating communications and electronic devices for DOD.

\section{Services:}

- Maintenance of electronics and communications equipment (satellite terminals, radio and radar systems, navigational equipment, including other specialized equipment).

\section{Letterkenny Army Depot}

Location: Chambersburg, Pennsylvania

Size: $7,080,000$ sq. $\mathrm{ft}$

Website: http://www.letterkenny.army.mil/

Letterkenny Depot is a part of the Army Aviation and Missile Command, dedicated to industrial operations and maintenance. The depot is located in south central Pennsylvania near Chambersburg.

\section{Services:}

- Mechanical capabilities: machining, sheet metal capabilities, welding, heat treatment, hydraulics, painting, plating, metal pretreatment, engine overhaul, among others

- Electronic capabilities: electronic system integration, wiring harness fabrication, fiber optic cables fabrication and repair, radar testing, among others. 


\section{Red River Army Depot}

Location: Texarkana, Texas

Size: $8,304,000$ sq. $\mathrm{ft}$

Website: http://www.redriver.army.mil//

Red River Depot is an industrial complex that maintains and supports the Army combat and tactical wheeled vehicles. Red River Depot has the only rubber product operations in the Army.

Services:

- Fabrication capabilities: rubber molding and fabrication of products, machining, welding, tool and die fabrication, metal finishing, chemical stripping, and painting among others.

\section{Anniston Army Depot}

Location: Anniston, Alabama

Size: $8,828,000$ sq. $\mathrm{ft}$

Website: http://www.anad.army.mil

Anniston Depot maintains both light and heavy tracked combat vehicles and components. The key organizations at Anniston are the Defense Distribution Depot, Munitions Center, Chemical Activity, and Chemical Demilitarization.

Services:

- Overhaul and repair combat vehicles

- Manufacturing including machining, milling, grinder, heat treating, plating and coating, tool and die, among others

- Small arms repair

- Fabrication including gaskets, hydraulic hoses, glass cutting, tool making.

\section{Hawthorne Army Depot}

Location: Hawthorne, Nevada

Size: $9,759,000$ sq. $\mathrm{ft}$

No other information is known at this time.

Table 1 summarizes the energy consumption of the identified Army sites. The data comes from a database maintained for the Renewable Energy Efficiency Program (REEP) - an energy analysis software tool developed by the U.S. Army Construction Engineering Research Laboratory (CERL). The column labeled "Cost/Electric Energy Index" gives a relative number for the cost of electricity. The table is sorted by this index from greatest to least to provide the reader with a prioritization in terms of cost of energy at the site. Also, the electric energy use intensity (EUI) is provided to show how the site uses electricity based on its floor area. Rock Island Arsenal ranks first in electric EUI and last in cost/energy index. 
Table 1. Site Energy Consumption of Key Army Industrial Sites - FY 2000 REEP Installation Data

\begin{tabular}{|c|c|c|c|c|c|c|c|c|c|}
\hline Installation & City & State & $\begin{array}{l}\text { Total } \\
\text { Area } \\
\text { (Ksf) }\end{array}$ & $\begin{array}{c}\text { Baseline Total } \\
\text { Energy Use } \\
\text { FY85 (MBtu) }\end{array}$ & $\begin{array}{l}\text { Electricity } \\
\text { Consumed } \\
(\mathbf{M W h} / \mathbf{y r})\end{array}$ & $\begin{array}{c}\text { Electricity, } \\
\text { Total Cost } \\
(\$ / y r)\end{array}$ & $\begin{array}{c}\text { Electric } \\
\text { Energy Use } \\
\text { Intensity } \\
(\mathbf{K W h} / \mathbf{s f})\end{array}$ & $\begin{array}{c}\text { Cost/ } \\
\text { Electric Energy } \\
\text { Index }(\$ / \mathbf{M W h})\end{array}$ & $\begin{array}{c}\text { Gas, Oil, } \\
\text { Coal Service } \\
\text { Total Cost } \\
(\$ / y \mathbf{r})\end{array}$ \\
\hline Picatinny Arsenal & Rockway & NJ & 3,907 & $1,179,317$ & 44,142 & $\$ 3,694,684$ & 11.298 & 83.70 & $\$ 2,814,976$ \\
\hline Watervliet Arsenal & Albany & NY & 2,162 & 797,572 & 36,847 & $\$ 3,077,821$ & 17.043 & 83.53 & $\$ 4,361,415$ \\
\hline Hawthorne Army Depot & Hawthorne & $\mathrm{NV}$ & 9,759 & 167,009 & 8,992 & $\$ 557,510$ & 0.921 & 62.00 & $\$ 906,141$ \\
\hline Corpus Christi Army Depot & Corpus Christi & TX & 2,185 & 372,637 & 56,667 & $\$ 3,176,856$ & 25.935 & 56.06 & $\$ 1,224,266$ \\
\hline Lake City AAP & Kansas City & MO & 3,165 & 747,892 & 39,309 & $\$ 2,013,306$ & 12.420 & 51.22 & $\$ 777,006$ \\
\hline Anniston Army Depot & Anniston & $\mathrm{AL}$ & 8,828 & 202,815 & 68,575 & $\$ 3,456,003$ & 7.768 & 50.40 & $\$ 1,516,882$ \\
\hline Letterkenny Army Depot & Chambersburg & $\mathrm{PA}$ & 7,080 & 429,902 & 42,102 & $\$ 1,946,593$ & 5.947 & 46.24 & $\$ 1,027,124$ \\
\hline Pine Bluff Arsenal & Pine Bluff & AR & 3,493 & 408,900 & 3,797 & $\$ 173,222$ & 1.087 & 45.62 & $\$ 83,418$ \\
\hline McAllester AAP & McAllester & $\mathrm{OK}$ & 9,805 & 299,727 & 13,994 & $\$ 318,957$ & 1.427 & 22.79 & $\$ 712,530$ \\
\hline Rock Island Arsenal & Rock Island & IL & 6,521 & $1,159,188$ & 178,118 & $\$ 1,033,200$ & 27.315 & 5.80 & $\$ 2,833,926$ \\
\hline
\end{tabular}




\section{AIR FORCE}

The primary Air Force industrial facilities are located at the Air Force Logistics Centers. These Air Force Bases have the main responsibility for the maintenance and repair of Air Force equipment, aircraft, and vehicles. Unlike the industrial facilities in the Army, the Air Force does not produce or manufacture parts, resulting in less energy intensive operations. The industrial facilities at the Air Force Logistics Centers primarily consist of large conditioned hangers that serve as the aircraft overhaul and maintenance shops, which include paint stripping, cleaning, and repainting of components; and stripping and re-plating of metal parts. The key industrial processes involved in these functions are:

- Paint stripping and paint booths

- Heat treating

- Electroplating

- Abrasive blasting

- Central compressed air system.

Tinker Air Force Base

Location: Tinker AFB, Oklahoma

Size: $15,163,954$ sq. $\mathrm{ft}$

Website: http://www-ext.tinker.af.mil/default.htm

Located outside of Oklahoma City, Oklahoma, Tinker Air Force Base staff rebuilds and refurbish aircraft. Tinker has been working with the local utility to implement energy-efficiency improvements in Tinker's industrial facilities, including the steam and air compression processes.

Processes:

- Large air compression unit, heat-treating, plating, and machining.

\section{Warner Robins Air Force Base}

Location: Robins AFB, Georgia

Size: $14,411,076$ sq. $\mathrm{ft}$

Website: http://www.robins.af.mil/index.htm

The Base has responsibility for worldwide management, repair, and overhaul of several key Air Force aircraft and helicopters and support equipment. Robins Air Force Base has performed upgrades to its central chiller plant and steam system.

\section{Hill Air Force Base}

Location: Hill AFB, Utah

Size: $14,767,000$ sq. $\mathrm{ft}$

Website: http://www.hill.af.mil/

Located in northern Utah, Hill Air Force Base is in the Air Force Material Command, supporting Ogden Air Logistics Center. The Base performs maintenance, repair, and logistics management on several key Air Force aircraft. Hill Air Force Base has implemented a comprehensive lighting and mechanical 
upgrade at its facility through the local utility. However, these upgrades most likely have not targeted industrial processes accept for the conditioned space and lighting of the hangers.

Table 2 summarizes the energy consumption of the Air Force sites identified in the task. Similar to the Army data provided in the previous section, the data in Table 2 was provided by CERL from a database maintained for REEP. However, because the Air Force has not reported up-to-date data for REEP, the most current installation data available for Air Force sites is FY1997.

\section{NAVY}

The Navy's primary industrial complexes are at Naval Ship Yards. The shipyards, like the Army Depots, are where all Navy ships and related equipment are repaired, overhauled, and maintained, which includes the mechanical, electrical, and structural overhaul. Typically, the energy use at shipyards is very sporadic because ships are worked on only when at dock. A list of common processes employed at Navy shipyards includes:

- Paint booths and paint stripping

- Heat treating

- Electroplating

- Abrasive blasting

- Welding

- Motor rewinding.

The Navy has some unique processes that include the fabrication and repair of large metal structures including:

- Pipefitting

- Shipfitting

- Boilermaking.

\section{Long Beach Naval Ship Yard}

Location: Long Beach, California

Size: $3,151,000$ sq. ft.

\section{Portsmouth Naval Ship Yard}

Location: Portsmouth, New Hampshire

Size: $4,046,000$ sq. $\mathrm{ft}$.

\section{Norfolk Naval Ship Yard}

Location: Norfolk, Virginia

Size: $6,300,000$ sq. $\mathrm{ft}$.

\section{Bremerton Naval Ship Yard}

Location: Puget Sound, Washington

Size: $5,406,000$ sq. $\mathrm{ft}$.

The data represented in Table 3 comes directly from the Naval Facilities Engineering Service Center - the Navy organization that maintains site-level energy data. 
Table 2. Site Energy Consumption of Key Air Force Industrial Sites - FY 1997 REEP Installation Data

\begin{tabular}{|c|c|c|c|c|c|r|r|}
\hline Installation & City & State & $\begin{array}{c}\text { Total Area } \\
\mathbf{( K s f )}\end{array}$ & $\begin{array}{c}\text { Electricity } \\
\text { Use } \\
(\mathbf{M W h} / \mathbf{y r})\end{array}$ & $\begin{array}{c}\text { Total Electricity } \\
\text { Cost } \mathbf{( \$ / y r )}\end{array}$ & $\begin{array}{c}\text { Electric } \\
\text { Energy Use } \\
\text { Intensity } \\
\mathbf{( K W h / s f )}\end{array}$ & $\begin{array}{c}\text { Cost/ } \\
\text { Electric Energy } \\
\text { Index } \mathbf{( \$ / M W h )}\end{array}$ \\
\hline \hline Robins Air Force Base & Robins AFB & GA & 14,411 & 261,945 & $\$ 11,591,151$ & 18.18 & 44.25 \\
\hline Hill Air Force Base & Hill AFB & UT & 14,767 & 233,942 & $\$ 7,909,973$ & 15.84 & 33.81 \\
\hline Tinker Air Force Base & Tinker AFB & OK & 15,164 & 351,737 & $\$ 10,857,751$ & 23.20 & 30.87 \\
\hline
\end{tabular}

Table 3. Site Energy Consumption of Key Naval Industrial Sites - FY 1998 Navy Data

\begin{tabular}{|l|l|l|r|r|r|r|r|r|}
\hline \multicolumn{1}{|c|}{ Installation } & \multicolumn{1}{|c|}{ City } & State & $\begin{array}{c}\text { Total } \\
\text { Area } \\
\mathbf{( K s f )}\end{array}$ & $\begin{array}{c}\text { Total } \\
\text { Electricity } \\
\text { Use } \\
\mathbf{( M W h / y r )}\end{array}$ & $\begin{array}{c}\text { Total Energy } \\
\text { Use } \\
\mathbf{( M B t u / y r )}\end{array}$ & $\begin{array}{c}\text { Total Energy } \\
\text { Cost } \\
\mathbf{( \$ / y r )}\end{array}$ & $\begin{array}{c}\text { Energy Use } \\
\text { Intensity } \\
\mathbf{( M B t u} / \mathbf{s f})\end{array}$ & $\begin{array}{c}\text { Cost/ } \\
\text { Energy } \\
\text { Index } \\
\mathbf{( \$ / M B t u )}\end{array}$ \\
\hline \hline Long Beach Naval Ship Yard & Long Beach & CA & 3,151 & 57,493 & 538,095 & $\$ 4,027,008$ & 0.17 & 7.48 \\
\hline Portsmouth Naval Ship Yard & Portsmouth & NH & 4,046 & 55,201 & $1,034,086$ & $\$ 6,038,010$ & 0.26 & 5.84 \\
\hline Bremerton Naval Ship Yard & Puget Sound & WA & 5,406 & 102,916 & $1,225,028$ & $\$ 4,763,300$ & 0.23 & 3.89 \\
\hline Norfolk Naval Ship Yard & Norfolk & VA & 6,300 & 35,867 & $2,273,068$ & $\$ 4,112,519$ & 0.36 & 1.81 \\
\hline
\end{tabular}




\section{CIVILIAN AGENCIES}

The primary civilian agencies that have large industrial facilities are Department of Energy, National Aeronautics and Space Administration, Department of Treasury, and General Services Administration. The sites that have been targeted as key industrial sites are summarized below.

\section{DEPARTMENT OF ENERGY}

The Department of Energy (DOE) has a significant number of energy intensive operations, as characterized in the Annual Report to Congress for FY 2000. While the sites categorized as energy intensive are primarily laboratory space, the following DOE sites have industrial facilities that may be good candidates for energy-efficiency projects:

- Kansas City Plant

- Sandia National Laboratory

- Petroleum and Oil Reserves.

\section{Kansas City Plant}

Location: Kansas City, Missouri

Size: 2,621,557 sq. $\mathrm{ft}$.

Website: $\underline{\text { http://www.os.kcp.com/about/index.html }}$

The Kansas City Plant is a state-of-the-art facility that manufactures a wide array of mechanical, electrical and engineered material components to support the national defense program. The plant's primary industrial processes include electronic manufacturing, mechanical services, engineered materials, and product testing.

\section{Electronic Manufacturing:}

- Microelectronics, microwave products, telemetry systems, automated robotics, test equipment, high energy products, electrical cables, welding services, among others.

\section{Mechanical Capabilities:}

- Fabrication of structural components and mechanical/electromechanical assemblies

- Services include precision cleaning, electromechanical assembly, miniature machining, precision machining, welding/brazing, sheet metal forming, among others.

Engineered Materials and Plastic Products:

- Adhesive joining, soldering, polymer production, painting/coating, plasma surface treating, manufacturing of plastics, rubber, and formed products.

\section{Sandia National Laboratory}

Location: Albuquerque, New Mexico

Size: 4,822,974 sq. ft.

Website: http://www.sandia.gov/ 
Sandia National Laboratory primarily houses laboratory/research and development facilities. However, the lab has key industrial processes that support the research and development mission. These include advanced manufacturing, microelectronics, and materials science.

Manufacturing Technology Center - This center develops manufacturing processes. The industrial processes that are used include:

- Bonding, coating, machining, ceramic processing, glass melting.

Microelectronics - Sandia houses a plant for the fabrication of and production of microelectronics and photonics. This laboratory is over 180,000 square feet comprised of laboratory space and a series of large fabrication clean rooms.

\section{Naval Petroleum and Oil Shale Reserves}

Location: Colorado and Wyoming

Size: 68,755 sq. ft.

Website: http://fossil.energy.gov/nposr/index.shtml

The Department of Energy manages petroleum and oil shale reserves. These reserves are not strictly classified as industrial facilities, but they are identified by DOE as energy intensive operations. These sites hold large reserves of petroleum in underground storage facilities that require large pumps to circulate the fluid. Therefore, these facilities may prove to be good candidates for high-efficiency motor replacements. There is also steam generation at these sites, which may provide areas for efficiency improvements.

Table 4 shows the process energy use for these sites, which excludes building energy (e.g., lights and heating, ventilation and air conditioning (HVAC)). The data in Table 4 was provided by DOE from the EMS3 system, which is the intranet database system that manages DOE's site level energy data. For the petroleum and oil reserves, only data from Casper, Wyoming Reserve was available. Also, the most recent data available was FY 1997.

Table 4. Process Energy Consumption of Key DOE Industrial Sites - FY 1997 (DOE)

\begin{tabular}{|l|l|r|r|r|r|r|r|}
\hline \multicolumn{1}{|c|}{ Installation } & City & State & $\begin{array}{c}\text { Total \# } \\
\text { of Bldgs }\end{array}$ & $\begin{array}{c}\text { Total } \\
\text { Area } \\
\text { (Ksf) }\end{array}$ & $\begin{array}{c}\text { Process } \\
\text { Electricity } \\
\text { Use } \\
(\mathbf{M W h} / \mathbf{y r})\end{array}$ & $\begin{array}{c}\text { Total Process } \\
\text { Energy Use } \\
\text { (MBtu/yr) }\end{array}$ & $\begin{array}{c}\text { Energy Use } \\
\text { Intensity } \\
\text { (MBtu/sf) }\end{array}$ \\
\hline \hline Sandia National Labs & Albuquerque & NM & 875 & 4,883 & $48,487.2$ & 242,607 & 0.05 \\
\hline Kansas City Plant & Kansas City & MO & 38 & 2,622 & DNA & DNA & DNA \\
\hline Naval Pet. Reserve No 3 & Casper & WY & 158 & 69 & $37,404.0$ & 568,880 & 8.59 \\
\hline
\end{tabular}

$\mathrm{DNA}=$ data not available 
NATIONAL AERONAUTICS AND SPACE ADMINISTRATION

Website: http://www.nasa.gov/

NASA energy intensive operations are mainly laboratory facilities with the focus of R\&D. However, three sites have been identified as industrial:

- Michoud Assembly Facility

- NASA Industrial Plan

- Marshall Space Flight Center.

Michoud Assembly Facility

Location: New Orleans, Louisiana

Size: $3,761,739$ sq. $\mathrm{ft}$

Michoud Assembly Facility is one of the key industrial facilities for NASA. This facility is run by Lockheed-Martin for NASA and is where the external tank is manufactured for the space shuttle. The plant produces about six tanks per year. The key processes at this site are not known at this time. Updates may be provided as the information is obtained

\section{NASA Industrial Plant}

Location: Downey and Palmdale, California

Size: $1,735,557$ sq. $\mathrm{ft}$

The NASA Industrial Plant is located in California at two sites -- Downey and Palmdale. The Downey site was in the process of closing in 2001. The Palmdale site is an aircraft manufacturing plant, where the space shuttle orbiters are repaired and upgraded. This facility is run by United Space Alliance for NASA. The key processes at this site are not known at this time. Updates may be provided as the information is obtained.

Marshall Space Flight Center

Location: Huntsville, Alabama

Size: $3,990,841$ sq. $\mathrm{ft}$

Marshall Space Flight Center covers over 1,800 acres with 220 buildings. Marshall's energy use has been categorized as $75 \%$ energy intensive by NASA, with the majority of this energy in R\&D, but some in industrial processes. Marshall is responsible for the critical components of the space shuttle and development and demonstration of other advanced aircraft, including space propulsion technology.

Table 5 shows site level energy data that represents the energy-intensive portion of the sites' total energy consumption. This energy excludes the energy used to operate the buildings (e.g., lights and HVAC). The data comes directly from NASA Headquarters. 
Table 5. Energy-Intensive Facility Energy Consumption of Key NASA Industrial Sites - FY 2000 (NASA)

\begin{tabular}{|c|c|c|c|c|c|c|c|c|c|}
\hline Installation & City & State & $\begin{array}{c}\text { Total \# of } \\
\text { Bldgs }\end{array}$ & $\begin{array}{c}\text { Total Area } \\
\text { (Ksf) }\end{array}$ & $\begin{array}{c}\text { Electricity } \\
\text { Use } \\
(\mathbf{M W h} / \mathbf{y r})\end{array}$ & $\begin{array}{c}\text { Total Energy } \\
\text { Use } \\
\text { (MBtu/yr) }\end{array}$ & \begin{tabular}{|c|} 
Total Energy \\
Cost $(\$ / y r)$
\end{tabular} & $\begin{array}{c}\text { Energy Use } \\
\text { Intensity } \\
\text { (MBtu/sf) }\end{array}$ & $\begin{array}{c}\text { Cost/ } \\
\text { Energy } \\
\text { Index } \\
\text { (\$/MBtu) }\end{array}$ \\
\hline Marshall Space Flight Center & Huntsville & $\mathrm{AL}$ & 220 & 3,991 & 110,172 & 577,413 & $\$ 8,361,000$ & 0.14 & 14.48 \\
\hline NASA Industrial Plant & $\begin{array}{l}\text { Downey \& } \\
\text { Palmdale }\end{array}$ & CA & 57 & 1,736 & 39,535 & 176,008 & $\$ 2,537,000$ & 0.10 & 14.41 \\
\hline Michoud Assembly Facility & New Orleans & LA & 38 & 3,762 & 119,174 & 957,804 & $\$ 8,901,000$ & 0.25 & 9.29 \\
\hline
\end{tabular}




\section{DEPARTMENT OF TREASURY}

The Department of Treasury (TRSY) is a relatively small agency, but it has some very large industrial facilities: the United States Mint and the Bureau of Engraving and Printing. The United States Mints are the world's largest manufacturer of coins, medals, and coin-based consumer products. The Bureau of Engraving and Printing produces currency notes and postage stamps.

\section{US Mint}

Website: http://www.usmint.gov/about the mint/.

\section{Denver Mint}

Location: Denver, Colorado

Size: 275,638 sq. ft.

The Denver Mint produces all coins for the west coast and commemorative coins. It is industrial space with steam, compressed air, and HVAC systems, sized accordingly. The Denver Mint is similar (has some of the same equipment to perform the same functions) to the Philadelphia Mint (which is described in more detail below), but smaller in size.

\section{San Francisco Mint}

Location: San Francisco, California

Size: 129,414 sq. ft.

The San Francisco Mint produces numismatic/collectible coins (gold, silver, platinum, etc.) plus medals and commemorative coins. It is industrial space with steam, compressed air, and HVAC systems, sized accordingly.

\section{West Point Mint}

Location: Within the West Point Military Academy military reservation, New York.

Size: 54,400 sq. ft.

The West Point Mint produces numismatic/collectible coins. It is industrial space with steam, compressed air, and HVAC systems, sized accordingly.

\section{Fort Knox Bullion Depository}

Location: Within Fort Knox Military Reservation, Kentucky

Size: 35,356 sq. ft.

This facility serves as a gold depository.

\section{Philadelphia Mint}

Location: Philadelphia, Pennsylvania

Size: 517,218 sq. ft.

(A detailed description of the Philadelphia Mint is provided. An extensive site visit of the facility was performed in support of another project prior to the development of this document.) 
The Philadelphia Mint is located in Philadelphia, Pennsylvania and has approximately 517,218 sq. ft. of floor space on four floors. The facility was built in 1969 and produces all coins for the east coast plus medals and commemorative coins.

Only about $10 \%$ to $15 \%$ of the floor space, is conditioned office space, with the remainder dedicated to coin production in an unconditioned industrial facility with 50 -foot ceilings. The space is divided by a central corridor and an enclosed tour gallery at the ceiling level. One side of the production space houses five Seco-Warwick rotary retort, indirect-fired continuous furnaces (with an integral quench bath and steam-drying drum) (purchased in 1995-1999) for annealing blanks. The other side of the production floor houses die-manufacturing equipment and an older electric furnace.

The major energy consuming systems are the process equipment (i.e., the furnaces), HVAC, lights, hot water, compressed air and the wastewater treatment system. The energy used includes natural gas, steam, and electricity. The steam is purchased from a local company, Trigen, with some condensate return used to preheat domestic hot water within the building. The steam is used in the furnace dryers, and for process hot water year-round and space heating seasonally.

There is heat recovery on furnace \#5 (i.e., an evaluation of recuperators was in progress in FY01) and no heat recovery on the other four furnaces. Each furnace has hood fans that pull off the furnace exhaust and discharge the heated air to the atmosphere.

The water treatment system includes two old (over 30 years-with some upgrades) cooling towers located on the roof. Typically, one is dedicated to process water and the other supplies the HVAC system (i.e., two new chillers located in an adjacent room). They have two centrifugal chillers, (a 300-ton Carrier and a 400-ton York). Normally, only one is used at a time, except on rare occasions in the summer, when they need both. Condensate and city water are used as make-up water for the treatment system.

If site-specific energy data is required, please contact the authors.

\section{Bureau of Engraving}

Website: http://www.bep.treas.gov/

The Bureau of Engraving and Printing (BEP) operates two facilities in Washington DC and Fort Worth, Texas. The BEP produces Federal Reserve notes as well as with postage stamps. Processes utilized at the BEP include tool and die, plating, engraving, and photographic processes.

\section{Washington DC BEP}

Location: Washington DC

Size: $1,377,200$ sq. ft.

Produces: reserve notes, postage stamps, and miscellaneous securities.

\section{Fort Worth BEP}

Location: Fort Worth, Texas

Size: 563,000 sq. ft.

Products: reserve notes only. 
If site-specific energy data is required, please contact the authors.

\section{GENERAL SERVICES ADMINISTRATION}

The General Services Administration (GSA) reported energy intensive operation data to FEMP for the first time in the FY 2000. The majority of the energy intensive facilities reported by GSA are US border stations. The border stations run 24 hours a day, 7 days a week, and often have large lighting loads, which classify these facilities in the EIOps category. However, for the purposes of this report, these border stations are not considered industrial.

The only industrial facility within GSA's EIOps category is the central steam plant located in Washington DC. This facility is the main driver of GSA's energy load in the EIOps category. This steam plant feeds steam and chilled water to a large number of GSA buildings and other Federal customers, such as the Smithsonian Institute. GSA is presently working with Washington Gas to implement a cogeneration project at the plant to deliver chilled water to the Smithsonian. No other detailed information is known about the site at this time.

Washington DC Steam Plant

Location: Washington DC

Size: 202,988 sq. ft.

If site-specific energy data is required, please contact the authors. 


\section{INFORMATION SOURCES}

\section{REFERENCES}

Lin, M. 1996. Review of Department of Defense Industrial Processes and Process Energy. US Army Corps of Engineers Construction Engineering Research Laboratories. August 1996.

U.S. Department of Energy, Federal Energy Management Program (FEMP). Annual Report to Congress on Federal Government Energy Management and Conservation Programs FY 2000 Draft. May 2001.

\section{INTERVIEWS}

Dixon, Doug. May 2001. Pacific Northwest National Laboratory. Phone conversations and email correspondence.

Dohery, Terry. May 2001. Pacific Northwest National Laboratory. Phone conversations and email correspondence.

Marchbanks, Gary. May, 2001. Oklahoma Gas and Electric. Email correspondence.

Meader, Dick. May, 2001. Pacific Northwest National Laboratory. Phone conversations and email correspondence.

Roop, Joe. May, 2001. Pacific Northwest National Laboratory. Phone conversations, interview, and email correspondence.

\section{WEBSITES}

National Aeronautics and Space Administration. Website: http://www.nasa.gov/

US Department of Energy. Kansas City Plant. Website: http://www.os.kcp.com/about/index.html

US Department of Energy. Naval Petroleum and Oil Shale Reserves . Website:

http://fossil.energy.gov/nposr/index.shtml

US Department of Energy. Sandia National Laboratory. Website: http://www.sandia.gov/

US Department of the Air Force. Hill Air Force Base. Website: http://www.hill.af.mil/

US Department of the Air Force. Tinker Air Force Base. Website: http://www-

ext.tinker.af.mil/default.htm

US Department of the Air Force. Warner Robins Air Force Base. Website:

http://www.robins.af.mil/index.htm

US Department of the Army. Anniston Army Depot. Website: http://www.anad.army.mil

US Department of the Army. Corpus Christi Depot. Website: http://www.ccad.army.mil/

US Department of the Army. Letterkenny Depot. Website: http://www.letterkenny.army.mil/ 
US Department of the Army. Pine Bluff Arsenal. Website: http://www.ria.army.mil/

US Department of the Army. Red River Army Depot. Website: http://www.redriver.army.mil/

US Department of the Army. Rock Island Arsenal. Website: http://www.ria.army.mil/

US Department of the Army. Tobyhanna Depot. Website: http://www.tobyhanna.army.mil/

US Department of the Army. Watervliet Arsenal. Website: http://www.wva.army.mil/MFG1.HTM

US Department of the Treasury. Bureau of Engraving and Printing. Website: http://www.bep.treas.gov/

US Department of the Treasury. US Mints. Website: http://www.usmint.gov/about the mint/. 
